\title{
Effects of gastrodin on 5-HT and neurotrophic factor in the treatment of patients with post-stroke depression
}

\author{
GANG LI ${ }^{1}$, YUNXIA MA ${ }^{1}$, JINMING JI ${ }^{1}$, XINGYAN SI ${ }^{2}$ and QIJIANG FAN ${ }^{1}$ \\ Departments of ${ }^{1}$ Neurology and ${ }^{2}$ Anesthesiology, Binzhou City Center Hospital, Binzhou, Shandong 251700, P.R. China
}

Received September 5, 2017; Accepted September 3, 2018

DOI: $10.3892 / \mathrm{etm} .2018 .6760$

\begin{abstract}
Effects of gastrodin on 5-HT and neurotrophic factor in the treatment of patients with post-stroke depression (PSD) were investigated. A total of 78 PSD patients were selected in Binzhou City Center Hospital from September 2013 to December 2016. Patients were randomly divided into the control group and experimental group, 39 patients in each group. Patients in the control group were treated with conventional drug fluoxertine hydrochloride for 2 months, and patients in the experimental group were treated with gastrodin. The levels of 5-HT and neurotrophic factors in blood were measured using the enzyme-linked immunosorbent assay (ELISA) kit before, and at 1 and 2 months after treatment. The Hamilton Depression Scale (HAMD), Activities of Daily Living (ADL) scale, NIH Stroke Scale/Score (NIHSS) and Stroke Impact Scale (SIS) were used to evaluate the efficacy of treatment. Treatment efficacy was compared between the two groups. The levels of 5-HT and neurotrophic factors were significantly higher in the experimental group than those in the control group at 1 and 2 months after treatment $(\mathrm{P}<0.05)$, and HAMD, ADL, NIHSS and SIS scores were all better in the experimental group than in the control group $(\mathrm{P}<0.05)$. In addition, significantly less side effects were found in the experimental group than that in the control group, and treatment efficacy in the experimental group was significantly better than that in the control group $(\mathrm{P}<0.05)$. Gastrodin is effective in the treatment of PSD and should be popularized.
\end{abstract}

\section{Introduction}

Post-stroke depression (PSD) is considered to be the most common and severe mental illness after stroke. Approximately one-third of stroke survivors suffer from severe depression, which can adversely affect a patient's cognitive function,

Correspondence to: Dr Gang Li, Department of Neurology, Binzhou City Center Hospital, 108 Huangchengnan Road, Huimin, Binzhou, Shandong 251700, P.R. China

E-mail: g584ed@163.com

Key words: post-stroke depression, neurotrophic factor, 5-HT, gastrodin functional recovery, and survival. It is generally believed that the damaged neural circuits of emotion regulation caused by stroke are the main cause of PSD. Gastrodin is one of the major active extracts of the root of Gastrodia elata Bl (1). Gastrodin is often used for anti-convulsions, analgesia, sedation, and is also used in the treatment of vertigo, paralysis and other diseases. In addition, studies have shown that gastrodin can promote learning and memory abilities (2). Gastrodin has also been proven to be able to protect cortical neurons and astrocytes from injury and reduce ischemic-induced neuronal damage $(3,4)$. However, the clinical effects of gastrodin on PSD have not been well studied.

As a neurotransmitter, 5-HT is involved in the regulation of pain, sleep and body temperature and other physiological functions. The abnormal content and function of 5-HT in the central nervous system may be associated with mental illness, migraine and other diseases (5). The neurotrophic factor (BDNF) is a brain-derived protein that plays an important role in the survival, differentiation, growth and development of neurons during the development of the central nervous system. Studies have shown that BDNF deficiency can lead to post-traumatic stress disorder, which is commonly known as phobia (6). The aim of this study was to investigate the effects of gastrodin on levels of 5-HT and BDNF in PSD patients and to assess the efficacy of gastrodin in the treatment of PSD.

\section{Patients and methods}

Clinical data. A total of 78 patients with PSD were selected from September 2013 to December 2016 in Binzhou City Center Hospital (Binzhou, China). The patients included 40 males and 38 females, and the age ranged from 48 to 76 years with an average age of $62.7 \pm 6.45$ years. This study was approved by the Ethics Committee of Binzhou City Center Hospital. All the patients signed an informed consent.

Diagnostic criteria for stroke. Stroke was diagnosed according to the 2014 edition of 'Guide to the diagnosis and treatment of acute cerebral ischemic stroke in China' (7): i) acute onset; ii) combined with systemic or focal neurological deficits; iii) neurological deficit signs and symptoms last longer than hours; iv) transcranial CT and magnetic resonance imaging (MRI) of ischemic lesions are consistent with clinical signs; and v) exclusion of non-vascular cerebral hemorrhage and brain lesions by brain CT and MRI. 
Table I. Comparison of the general information between two groups.

\begin{tabular}{|c|c|c|c|c|}
\hline Items & Control group $(n=39)$ & Experimental group $(n=39)$ & $\chi^{2}$ value & P-value \\
\hline Age (years) & $65.10 \pm 9.5$ & $66.72 \pm 7.9$ & 1.45 & 0.934 \\
\hline Sex (male) n (\%) & $21(53.85 \%)$ & $19(48.72 \%)$ & 1.43 & 0.981 \\
\hline Stroke type n (\%) & & & 3.87 & 0.726 \\
\hline Atherosclerosis & $14(35.90 \%)$ & $13(33.33 \%)$ & & \\
\hline Cardiac embolism & $11(28.21 \%)$ & $12(30.77 \%)$ & & \\
\hline Lacunar infarction & $13(33.33 \%)$ & $10(25.64 \%)$ & & \\
\hline Other & $1(2.56 \%)$ & $4(10.26 \%)$ & & \\
\hline Course of PSD (days) & $22.51 \pm 3.73$ & $24.67 \pm 2.87$ & 4.75 & 0.254 \\
\hline
\end{tabular}

Diagnostic criteria for anxiety and depression. Anxiety and depression were diagnosed according to the diagnostic criteria described in the 'Chinese Mental Disorder Classification and Diagnosis Standards 3rd Edition' proposed by the Chinese Medical Association Psychiatric Branch (8): i) loss of pleasure and interest; ii) fatigue and limited energy; iii) long-term low self-evaluation; iv) reduced self-thinking ability, manifested as mental retardation or excitement; v) sleep disorder; vi) self-injury and motivation; and vii) libido, appetite, and body weight different from what they used to be prior to PSD.

Inclusion criteria. i) All patients included in this study were clinically diagnosed with stroke diagnosis; ii) patients without drug allergies; iii) patients who had no anxiety and depression before stroke; and iv) patients who had clear consciousness and certain communication skills.

Exclusion criteria. i) patients with anxiety and depressive symptoms; ii) patients with suicidal tendencies; iii) patients with nervous system dysfunction and past severe heart, liver, and kidney dysfunction; iv) patients with history of drug allergies; v) patients who were treated within 7 days before admission; and vi) patients unable to complete treatment.

Treatment. The 78 patients were randomly divided into the control group (21 were males and 18 were females) and experimental group (18 were males and 21 were females), 39 cases in each group. Patients in the control group were treated with conventional drug fluoxetine hydrochloride capsules (Lilly Suzhou Pharmaceutical Group Co., Ltd., Suzhou, China; SFDA approval no. J20130010) with a dose of $12.5 \mathrm{mg}$ each time and 3 times per day. Patients in the control group were treated with gastrodin capsules (KPC Pharmaceuticals Inc., Kunming, China; SFDA approval no. H20013043) with a dose of $25 \mathrm{mg}$ each time and 3 times per day. All patients were treated for 2 months.

Measurement of indicators. Hamilton Depression (HAMD) scale, Activities of Daily Living (ADL) scale, NIH Stroke Scale/Score (NIHSS) and Stroke Impact Scale (SIS) scoring were performed by the same physician before, and at 1 and 2 months after treatment. Blood samples were collected from each patient before and at 1 and 2 months after treatment. The levels of neurotrophic factor (BDNF) and 5-hydroxytryptamine (5-HT) were measured using the BDNF ELISA kit (cat. no. 3765; R\&D Systems, Inc., Minneapolis, MN, USA) and 5-HT ELISA kit (cat. no. 4493; R\&D Systems, Inc.). Side effects mainly include systemic or local allergies, gastrointestinal disorders (such as nausea, vomiting, dyspepsia, diarrhea and dysphagia), anorexia, dizziness, headache, abnormal sleep, fatigue, mental state abnormalities, visual abnormalities, xeromycteria, dizziness and stomach upset. Adverse effects were recorded. Total effective rate $(\%)=$ (number of cured patients + number of patients showed partial improvement)/total number of patients.

Statistical analysis. Data were analyzed by GraphPad Prism software (version 5.01). Measurement data were expressed as mean \pm SD. ANOVA was used for comparison between multiple groups and the post hoc test was Dunnett's test. Percentage (\%) was used to express the enumeration data and Chi-square test was used for data analysis. $\mathrm{P}<0.05$ was considered to indicate a statistically significant difference.

\section{Results}

Comparison of the general information between the two groups of patients. As shown in Table I, no significant differences in age, sex, types of stroke and course of PSD were found between the two groups $(\mathrm{P}>0.05)$.

Comparison of 5-HT levels between the two groups before and after treatment. Before treatment, no significant differences in the levels of 5-HT were found between the two groups $(\mathrm{P}>0.05)$. Compared with the preoperative levels, the 5 -HT levels were significantly increased in the two groups of patients at 1 and 2 months after treatment $(\mathrm{P}<0.05)$. In addition, the 5-HT levels were significantly higher in the experimental group than those in the control group at 1 and 2 months after treatment $(\mathrm{P}<0.05$; Table II).

Comparison of BDNF levels between the two groups before and after treatment. No significant differences in the levels of BDNF were found between the two groups before treatment $(\mathrm{P}>0.05)$. Compared with the preoperative levels, the BDNF levels were significantly increased in the two groups of patients at 1 and 2 months after treatment $(\mathrm{P}<0.05)$. In addition, the levels of BDNF were significantly higher in the experimental 
Table II. Comparison of 5-HT levels between the two groups before and after treatment (mean $\pm \mathrm{SD}, \mathrm{ng} / \mathrm{ml})$.

\begin{tabular}{lcccc}
\hline Groups & $\mathrm{n}$ & Before treatment & $\begin{array}{c}1 \text { month after } \\
\text { treatment }\end{array}$ & $\begin{array}{c}2 \text { months after } \\
\text { treatment }\end{array}$ \\
\hline Control group & 39 & $65.34 \pm 8.45$ & $92.57 \pm 10.58^{\mathrm{a}}$ & $124.64 \pm 14.05^{\mathrm{b}}$ \\
Experimental group & 39 & $67.51 \pm 7.02$ & $107.82 \pm 10.23^{\mathrm{b}, \mathrm{d}}$ & $148.51 \pm 12.83^{\mathrm{c}, \mathrm{d}}$ \\
t value & & 0.552 & 1.232 & 1.784 \\
P-value & & 0.683 & 0.0371 & 0.0107 \\
\hline
\end{tabular}

${ }^{\mathrm{a}} \mathrm{P}<0.05$ compared with the preoperative level; ${ }^{\mathrm{b}} \mathrm{P}<0.01$ compared with the preoperative level; ${ }^{\mathrm{C}} \mathrm{P}<0.001$ compared with the preoperative level; ${ }^{\mathrm{d}} \mathrm{P}<0.05$ compared with the control group.

Table III. Comparison of BDNF levels between the two groups before and after treatment (mean $\pm \mathrm{SD}, \mathrm{ng} / \mathrm{ml}$ ).

\begin{tabular}{lcccc}
\hline Groups & $\mathrm{n}$ & Before treatment & $\begin{array}{c}1 \text { month after } \\
\text { treatment }\end{array}$ & $\begin{array}{c}2 \text { months after } \\
\text { treatment }\end{array}$ \\
\hline Control group & 39 & $8.03 \pm 1.72$ & $14.09 \pm 2.16^{\mathrm{a}}$ & $19.29 \pm 3.62^{\mathrm{b}}$ \\
Experimental group & 39 & $7.67 \pm 1.53$ & $18.38 \pm 2.07^{\mathrm{a}, \mathrm{c}}$ & $25.78 \pm 4.41^{\mathrm{b}, \mathrm{c}}$ \\
t value & & 0.348 & 0.984 & 1.127 \\
P-value & & 0.829 & 0.0403 & 0.0336 \\
\hline
\end{tabular}

${ }^{\text {a }} \mathrm{P}<0.05$ compared with the preoperative level; ${ }^{\mathrm{b}} \mathrm{P}<0.01$ compared with the preoperative level; ${ }^{\mathrm{c}} \mathrm{P}<0.05$ compared with the control group.

Table IV. Comparison of HAMD scores between the two groups of patients before and after treatment (mean \pm SD).

\begin{tabular}{lcccc}
\hline Groups & $\mathrm{n}$ & Before treatment & $\begin{array}{c}1 \text { month after } \\
\text { treatment }\end{array}$ & $\begin{array}{c}\text { months after } \\
\text { treatment }\end{array}$ \\
\hline Control group & 39 & $27.37 \pm 1.65$ & $17.58 \pm 1.43^{\mathrm{a}}$ & $12.96 \pm 0.79^{\mathrm{b}}$ \\
Experimental group & 39 & $26.83 \pm 1.84$ & $12.26 \pm 1.51^{\mathrm{a}, \mathrm{c}}$ & $7.92 \pm 0.98^{\mathrm{b}, \mathrm{c}}$ \\
t value & & 0.380 & 0.946 & 1.165 \\
P-value & & 0.675 & 0.0366 & 0.0341 \\
\hline
\end{tabular}

${ }^{a} \mathrm{P}<0.05$ compared with the preoperative level; ${ }^{b} \mathrm{P}<0.01$ compared with the preoperative level; ${ }^{\mathrm{c}} \mathrm{P}<0.05$ compared with the control group.

Table V. Comparison of ADL and NIHSS scores between the two groups before and after treatment (mean \pm SD).

\begin{tabular}{llcccc}
\hline \multirow{2}{*}{ Items } & \multicolumn{1}{c}{ Groups } & n & Before treatment & $\begin{array}{c}1 \text { month after } \\
\text { treatment }\end{array}$ & $\begin{array}{c}2 \text { months after } \\
\text { treatment }\end{array}$ \\
\hline ALD & Control group & 39 & $54.57 \pm 6.87$ & $67.19 \pm 7.30^{\mathrm{a}}$ & $74.14 \pm 8.22^{\mathrm{b}}$ \\
& Experimental group & 39 & $55.79 \pm 7.82$ & $72.04 \pm 8.93^{\mathrm{a}, \mathrm{c}}$ & $91.36 \pm 9.69^{\mathrm{b}, \mathrm{c}}$ \\
& t value & & 0.576 & 1.664 & 2.486 \\
& P-value & & 0.728 & 0.0207 & 0.00839 \\
NIHSS & Control group & 39 & $20.45 \pm 1.88$ & $16.76 \pm 1.74^{\mathrm{a}}$ & $12.73 \pm 1.96^{\mathrm{a}}$ \\
& Experimental group & 39 & $21.31 \pm 2.04$ & $13.06 \pm 1.78^{\mathrm{a}, \mathrm{c}}$ & $7.78 \pm 1.53^{\mathrm{b}, \mathrm{c}}$ \\
& t value & & 0.453 & 1.352 & 0.0458 \\
\hline
\end{tabular}

${ }^{\mathrm{a}} \mathrm{P}<0.05$ compared with the preoperative level; ${ }^{\mathrm{b}} \mathrm{P}<0.01$ compared with the preoperative level; ${ }^{\mathrm{c}} \mathrm{P}<0.05$ compared with the control group.

group than those in the control group at 1 and 2 months after treatment $(\mathrm{P}<0.05)($ Table III).
Comparison of HAMD scores between the two groups of patients before and after treatment. There were no significant 
Table VI. Comparison of SIS scores between the two groups before and after treatment (mean \pm SD).

\begin{tabular}{|c|c|c|c|c|c|}
\hline Items & Groups & $\mathrm{n}$ & Before treatment & $\begin{array}{l}1 \text { month after } \\
\text { treatment }\end{array}$ & $\begin{array}{c}2 \text { months after } \\
\text { treatment }\end{array}$ \\
\hline Strength & $\begin{array}{l}\text { Control group } \\
\text { Experimental group } \\
\text { t value } \\
\text { P-value }\end{array}$ & $\begin{array}{l}39 \\
39\end{array}$ & $\begin{array}{c}65.45 \pm 5.23 \\
64.50 \pm 5.85 \\
0.434 \\
0.681\end{array}$ & $\begin{array}{c}70.56 \pm 6.44^{\mathrm{a}} \\
75.33 \pm 7.72^{\mathrm{a}, \mathrm{c}} \\
0.893 \\
0.0403\end{array}$ & $\begin{array}{c}76.31 \pm 7.72^{\mathrm{a}} \\
82.76 \pm 9.82^{\mathrm{b}, \mathrm{c}} \\
0.932 \\
0.0394\end{array}$ \\
\hline Hand function & $\begin{array}{l}\text { Control group } \\
\text { Experimental group } \\
\text { t value } \\
\text { P-value }\end{array}$ & $\begin{array}{l}39 \\
39\end{array}$ & $\begin{array}{c}48.08 \pm 4.76 \\
48.53 \pm 4.37 \\
0.595 \\
0.890\end{array}$ & $\begin{array}{c}52.61 \pm 5.73^{\mathrm{a}} \\
55.17 \pm 6.34^{\mathrm{a}, \mathrm{c}} \\
0.752 \\
0.0417\end{array}$ & $\begin{array}{c}58.42 \pm 6.31^{\mathrm{a}} \\
61.94 \pm 4.66^{\mathrm{b}, \mathrm{c}} \\
1.135 \\
0.0381\end{array}$ \\
\hline Mood & $\begin{array}{l}\text { Control group } \\
\text { Experimental group } \\
\text { t value } \\
\text { P-value }\end{array}$ & $\begin{array}{l}39 \\
39\end{array}$ & $\begin{array}{c}60.74 \pm 3.24 \\
59.37 \pm 3.38 \\
0.674 \\
0.715\end{array}$ & $\begin{array}{c}63.45 \pm 3.86^{\mathrm{a}} \\
66.83 \pm 4.29^{\mathrm{a}, \mathrm{c}} \\
0.914 \\
0.0487\end{array}$ & $\begin{array}{c}67.27 \pm 4.15^{\mathrm{a}} \\
73.74 \pm 4.86^{\mathrm{b}, \mathrm{c}} \\
1.382 \\
0.0176\end{array}$ \\
\hline Communication & $\begin{array}{l}\text { Control group } \\
\text { Experimental group } \\
\text { t value }\end{array}$ & $\begin{array}{l}39 \\
39\end{array}$ & $\begin{array}{c}78.22 \pm 7.84 \\
77.39 \pm 7.30 \\
0.526\end{array}$ & $\begin{array}{c}81.36 \pm 8.36^{\mathrm{a}} \\
84.66 \pm 8.59^{\mathrm{a}, \mathrm{c}} \\
0.876\end{array}$ & $\begin{array}{l}85.58 \pm 9.57^{\mathrm{a}} \\
92.68 \pm 10.06^{\mathrm{b}, \mathrm{c}} \\
1.226\end{array}$ \\
\hline Activity & $\begin{array}{l}\text { P-value } \\
\text { Control group } \\
\text { Experimental group } \\
\text { t value }\end{array}$ & $\begin{array}{l}39 \\
39\end{array}$ & $\begin{array}{c}0.662 \\
65.92 \pm 10.66 \\
66.53 \pm 9.84 \\
0.487\end{array}$ & $\begin{array}{c}0.0429 \\
68.94 \pm 10.37^{\mathrm{a}} \\
71.44 \pm 11.27^{\mathrm{a}, \mathrm{c}} \\
0.994\end{array}$ & $\begin{array}{c}0.0203 \\
71.64 \pm 11.09^{\mathrm{a}} \\
76.63 \pm 11.85^{\mathrm{a}, \mathrm{c}} \\
0.987\end{array}$ \\
\hline Action & $\begin{array}{l}\text { P-value } \\
\text { Control group } \\
\text { Experimental group } \\
\text { t value } \\
\text { P-value }\end{array}$ & $\begin{array}{l}39 \\
39\end{array}$ & $\begin{array}{c}0.770 \\
72.25 \pm 11.67 \\
72.94 \pm 11.40 \\
0.502 \\
0.693\end{array}$ & $\begin{array}{c}0.0311 \\
75.88 \pm 11.24^{\mathrm{a}} \\
77.98 \pm 10.45^{\mathrm{a}, \mathrm{c}} \\
1.153 \\
0.0265\end{array}$ & $\begin{array}{c}0.0462 \\
79.15 \pm 11.08^{\mathrm{a}} \\
83.56 \pm 12.36^{\mathrm{a}, \mathrm{c}} \\
1.432 \\
0.0201\end{array}$ \\
\hline
\end{tabular}

${ }^{\mathrm{a}} \mathrm{P}<0.05$ compared with the preoperative level; ${ }^{\mathrm{b}} \mathrm{P}<0.01$ compared with the preoperative level; ${ }^{\mathrm{c}} \mathrm{P}<0.05$ compared with the control group.

Table VII. Comparison of treatment efficacy between the two groups.

\begin{tabular}{|c|c|c|c|c|c|c|c|}
\hline Groups & $\mathrm{n}$ & Side effects & Percentage & Cure & Effective & Ineffective & Total effective rate \\
\hline Control group & 39 & 11 & $28.21 \%$ & 14 & 12 & 13 & $66.67 \%$ \\
\hline Experimental group & 39 & 7 & $17.95 \% \mathrm{a}^{\mathrm{a}}$ & 19 & 15 & 5 & $87.18 \%{ }^{a}$ \\
\hline$\chi^{2}$ value & & & 1.65 & & & & 1.79 \\
\hline P-value & & & 0.0285 & & & & 0.0327 \\
\hline
\end{tabular}

${ }^{\mathrm{a}} \mathrm{P}<0.05$ compared with the control group.

differences in HAMD scores between the two groups before treatment $(\mathrm{P}>0.05)$. Compared with the preoperative levels, HAMD scores were significantly decreased in the two groups of patients at 1 and 2 months after treatment $(\mathrm{P}<0.05)$. Compared with the control group, HAMD scores were significantly reduced in the experimental group $(\mathrm{P}<0.05)$ (Table IV).

Comparison of ADL and NIHSS scores between the two groups before and after treatment. As shown in Table V, compared with the preoperative levels, ADL scores were significantly increased and NIHSS scores were significantly decreased in both groups at 1 and 2 months after treatment $(\mathrm{P}<0.05)$. Compared with the control group, significantly higher ADL scores and lower NIHSS scores were found in the experimental group at 1 and 2 months after treatment $(\mathrm{P}<0.05)$.

Comparison of SIS scores between the two groups before and after treatment. This study evaluated 6 items including strength, hand function, mood, communication, activity and action. As shown in Table VI, no significant differences in SIS scores were found between the two groups before treatment. SIS scores were significantly increased in both groups 
at 1 month and 2 months after treatment $(\mathrm{P}<0.05)$. In addition, SIS scores were higher in the experimental group than those in the control group $(\mathrm{P}<0.05)$.

Comparison of treatment efficacy between the two groups. Two months after treatment, 11 patients in the control group showed side effects, 14 cases were cured, 12 cases were effective, and 13 cases were invalid, and the total effective rate was $66.67 \%$ (26/39). While, only 7 cases in the experimental group showed side effects, 19 cases were cured, 15 cases were effective, and 5 cases were invalid, and the total effective rate was $87.18 \%$ (34/39). Therefore, treatment efficacy was significantly higher in the experimental group than that in the control group $(\mathrm{P}<0.05)$ (Table VII).

\section{Discussion}

With an aging population that continues to grow, the incidence of hypertension, diabetes, hyperlipidemia and other stroke related diseases are increasing, which in turn leads to the increased incidence of stroke $(8,9)$. PSD is the most common complication of stroke. The incidence of PSD in China is estimated to be approximately 30-35\%, and many patients develop depression several hours to several days after stroke (10). There are two opposing views on the mechanism for the occurrence of PSD. It is believed that the damaged neural circuits of emotion regulation and central nervous system induced by ischemic injury after stroke are the main cause of PSD $(11,12)$. While other studies have shown that stroke-related social and psychological stress is the main cause of PSD $(13,14)$.

Conventional treatment of PSD includes controlling hypertension, reducing high cholesterol, prohibiting smoking, blocking excitatory neurotransmitters, preventing cerebral ischemia, or scavenging free radicals $(15,16)$, but those treatments usually fail to provide satisfactory treatment outcomes. As an adjunctive therapy, Chinese medicine becomes more and more important in the treatment of PSD. For example, Hypericumperfortum extracts have been proven to be effective in the treatment of depression (17). In this study, gastrodin was used to treat PSD and showed excellent clinical therapeutic effects. Studies have shown that gastrodin is an important component extracted from traditional Chinese medicine gastrodia, which is a commonly used drug for clinical treatment. Gastrodin can remove free radicals in the body, delay the process of apoptosis, protect cell membranes, and simultaneously expand blood vessels and regulate blood viscosity and compliance. In addition, gastrodin can inhibit the production of monoamine oxidase, increase brain dopamine and 5-HT contents, thereby exerting anxiolytic and depressive effects $(18,19)$. This study selected gastrodin as a research object for the treatment of PSD and excellent clinical effects were observed.

BDNF and 5-HT play pivotal roles in the regulation of synaptic plasticity in adult (20). As a member of the family of neurotrophic factors, BDNF plays a pivotal role in brain development and plasticity by promoting nerve regeneration, synaptic plasticity and cell survival $(21,18)$. 5-HT is produced by neurons located in the brain stem, and it can also promote the survival of neurons in the adult brain (19). The axons that produce 5-HT neurons dominate normative behavior in multiple cerebral cortical and subcortical regions including cognition and mood $(22,23)$. Disrupted 5-HT and BDNF signaling pathways are the main causes of depression, and studying the levels of 5-HT and BDNF in PSD patients is an important way to expose the molecular mechanism.

In this study, we found that gastrodin could significantly increase the levels of 5-HT and BDNF in patients with PSD. In addition, HAMD and NIHSS scores were significantly decreased and ADL and SIS scores were significantly increased at 1 and 2 months after treatment with gastrodin. Compared with fluoxetine hydrochloride, gastrodin has less side effects and good efficiency. Gastrodin can effectively alleviate depression and improve the quality of life of patients. In conclusion, gastrodin can be used to effectively treat PSD and should be popularized in clinical practices.

\section{Acknowledgements}

Not applicable.

\section{Funding}

No funding was received.

\section{Availability of data and materials}

The datasets used and/or analyzed during the present study are available from the corresponding author on reasonable request.

\section{Authors' contributions}

GL drafted the manuscript. GL and YM were mainly devoted to collecting and interpreting the data. JJ and XS revised it critically for important intellectual content and were also involved in the conception and design of the study. QF was responsible for the conception and design of the study. All authors have read and approved the final manuscript.

\section{Ethics approval and consent to participate}

The study was approved by the Ethics Committee of Binzhou City Center Hospital (Binzhou, China). Signed informed consents were obtained from the patients.

\section{Patient consent for publication}

Not applicable.

\section{Competing interests}

The authors declare that they have no competing interests.

\section{References}

1. Peng Z, Wang S, Chen G, Cai M, Liu R, Deng J, Liu J, Zhang T, Tan Q and Hai C: Gastrodin alleviates cerebral ischemic damage in mice by improving anti-oxidant and anti-inflammation activities and inhibiting apoptosis pathway. Neurochem Res 40: 661-673, 2015.

2. Wong SB, Hung WC and Min MY: The role of gastrodin on hippocampal neurons after N-methyl-D-aspartate excitotoxicity and experimental temporal lobe seizures. Chin J Physiol 59: 156-164, 2016. 
3. Wang X, Yan S, Wang A, Li Y and Zhang F: Gastrodin ameliorates memory deficits in 3,3'-iminodipropionitrile-induced rats: Possible involvement of dopaminergic system. Neurochem Res 39: 1458-1466, 2014.

4. Kumar H, Kim IS, More SV, Kim BW, Bahk YY and Choi DK: Gastrodin protects apoptotic dopaminergic neurons in a toxininduced Parkinson's disease model. Evid Based Complement Alternat Med 2013: 514095, 2013.

5. Viguier F, Michot B, Hamon M and Bourgoin S: Multiple roles of serotonin in pain control mechanisms - implications of 5-HT(7) and other 5-HT receptor types. Eur J Pharmacol 716: 8-16, 2013.

6. Lv QQ, Wu WJ, Guo XL, Liu RL, Yang YP, Zhou DS, Zhang JX and Liu JY: Antidepressant activity of astilbin: Involvement of monoaminergic neurotransmitters and BDNF signal pathway. Biol Pharm Bull 37: 987-995, 2014.

7. Bugarski Ignjatovic V, Semnic M, Gebauer Bukurov K and Kozic D: Cognitive impairment and functional ability in the acute phase of ischemic stroke. Eur Rev Med Pharmacol Sci 19 3251-3256, 2015

8. Gaete JM and Bogousslavsky J: Post-stroke depression. Expert Rev Neurother 8: 75-92, 2008

9. Kauhanen M, Korpelainen JT, Hiltunen P, Brusin E, Mononen H, Määttä R, Nieminen P, Sotaniemi KA and Myllylä VV: Poststroke depression correlates with cognitive impairment and neurological deficits. Stroke 30: 1875-1880, 1999.

10. De Ryck A, Brouns R, Geurden M, Elseviers M, De Deyn PP and Engelborghs S: Risk factors for poststroke depression: Identification of inconsistencies based on a systematic review. J Geriatr Psychiatry Neurol 27: 147-158, 2014.

11. Robinson RG, Starr LB and Price TR: A two year longitudinal study of mood disorders following stroke. Prevalence and duration at six months follow-up. Br J Psychiatry 144: 256-262, 1984.

12. Salinas J, Ray RM, Nassir R, Lakshminarayan K, Dording C, Smoller J, Wassertheil-Smoller S, Rosand J and Dunn EC: Factors associated with New-Onset depression following ischemic stroke: The women's health initiative. J Am Heart Assoc 6: 6, 2017.

13. Mazure CM, Weinberger AH, Pittman B, Sibon I and Swendsen J: Gender and stress in predicting depressive symptoms following stroke. Cerebrovasc Dis 38: 240-246, 2014.

14. Wang SY, Wang M, Wang XX, Chen W, Sheng C and Gong ZK Study on the clinical application of the MRS in the cognitive assessment after stroke. Eur Rev Med Pharmacol Sci 21: 2437-2442, 2017.
15. Paolucci S: Advances in antidepressants for treating post-stroke depression. Expert Opin Pharmacother 18: 1011-1017, 2017.

16. Flaster M, Sharma A and Rao M: Poststroke depression: A review emphasizing the role of prophylactic treatment and synergy with treatment for motor recovery. Top Stroke Rehabil 20: 139-150, 2013.

17. Hammerness P, Basch E, Ulbricht C, Barrette EP, Foppa I, Basch S, Bent S, Boon H and Ernst E; Natural Standard Research Collaboration: St John's wort: A systematic review of adverse effects and drug interactions for the consultation psychiatrist. Psychosomatics 44: 271-282, 2003.

18. Larsson E, Nanobashvili A, Kokaia Z and Lindvall O: Evidence for neuroprotective effects of endogenous brain-derived neurotrophic factor after global forebrain ischemia in rats. J Cereb Blood Flow Metab 19: 1220-1228, 1999.

19. Strüder HK and Weicker H: Physiology and pathophysiology of the serotonergic system and its implications on mental and physical performance. Part I. Int J Sports Med 22: 467-481, 2001.

20. Chhibber A, Woody SK, Karim Rumi MA, Soares MJ and Zhao L: Estrogen receptor $\beta$ deficiency impairs BDNF-5-HT2A signaling in the hippocampus of female brain: A possible mechanism for menopausal depression. Psychoneuroendocrinology 82: 107-116, 2017.

21. Lee J, Duan W and Mattson MP: Evidence that brain-derived neurotrophic factor is required for basal neurogenesis and mediates, in part, the enhancement of neurogenesis by dietary restriction in the hippocampus of adult mice. J Neurochem 82: 1367-1375, 2002.

22. Gaspar P, Cases O and Maroteaux L: The developmental role of serotonin: News from mouse molecular genetics. Nat Rey Neurosci 4: 1002-1012, 2003.

23. Santarelli L, Saxe M, Gross C, Surget A, Battaglia F, Dulawa S, Weisstaub N, Lee J, Duman R, Arancio O, et al: Requirement of hippocampal neurogenesis for the behavioral effects of antidepressants. Science 301: 805-809, 2003. International (CC BY-NC-ND 4.0) License. 